\title{
A STRATEGIC COST-BENEFIT ANALYSIS OF ENERGY POLICIES: OVERVIEW
}

Harry Davitian, Richard J. Goettle IV, Paul J. Groncki, Edward A. Hudson, Peter Kleeman, and Joan Lukachinski

October 1979

NATIONAL CENTER FOR ANALYSIS OF ENERGY SYSTEMS DEPARTMENT OF ENERGY AND ENVIRONMENT

BROOKHAVEN NATIONAL LABORATORY UPTON, NEW YORK 11973 


\section{DISCLAIMER}

This report was prepared as an account of work sponsored by an agency of the United States Government. Neither the United States Government nor any agency Thereof, nor any of their employees, makes any warranty, express or implied, or assumes any legal liability or responsibility for the accuracy, completeness, or usefulness of any information, apparatus, product, or process disclosed, or represents that its use would not infringe privately owned rights. Reference herein to any specific commercial product, process, or service by trade name, trademark, manufacturer, or otherwise does not necessarily constitute or imply its endorsement, recommendation, or favoring by the United States Government or any agency thereof. The views and opinions of authors expressed herein do not necessarily state or reflect those of the United States Government or any agency thereof. 


\section{DISCLAIMER}

Portions of this document may be illegible in electronic image products. Images are produced from the best available original document. 
BNL 51105

UC-95c

(Energy Conservation-Systems Modeling and Performance Assessment - TID-4500)

\title{
A STRATEGIC COST-BENEFIT ANALYSIS OF ENERGY POLICIES: OVERVIEW
}

\author{
HaRry DaVitian \\ PaUl J. GRONCKI \\ Peter KLeEman \\ JOAN LUKACHINSKI \\ National Center for Analysis of Energy Systems \\ Brookhaven National Laboratory \\ Richard J. GOETtLE IV \\ EDWARd A. HudSON \\ Dale W. Jorgenson Associates \\ ECONOMIC ANALYSIS DIVISION \\ NATIONAL CENTER FOR ANALYSIS OF ENERGY SYSTEMS \\ DEPARTMENT OF ENERGY AND ENVIRONMENT \\ BROOKHAVEN NATIONAL LABORATORY \\ ASSOCIATED UNIVERSITIES, INC.
}

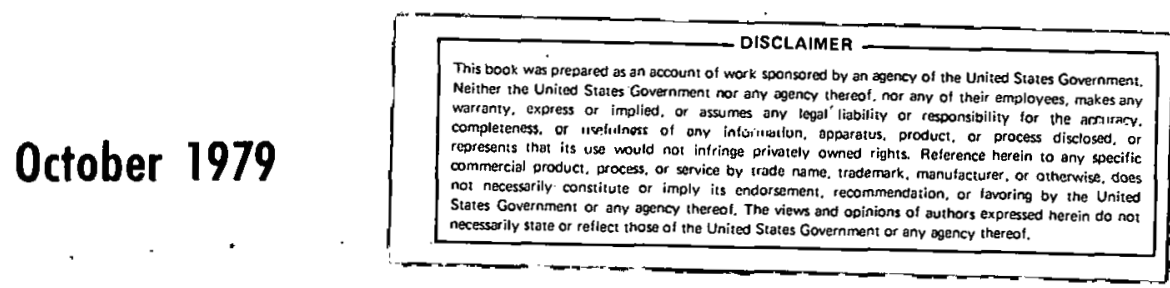

Prepared for the Office of Policy, Planning and Evaluation, Conservation and Solar Applications, U.S. Department of Energy under

Contract No. DE-ACO2-76CH00016 


\section{DISCLAIMER}

This book was prepared as an ar.rnunt of work sponsored by an agency of the United States Government. Neither the United States Government nor any agency thereof, nor any of their employees, makes any warranty, express or implied, or assumes any legal liability or responsibility for the accuracy, completeness, or usefulness of any information, apparatus, product, or process disclosed, or represents that its use would not infringe privately owned rights. Reference herein to any specific commercial product, process, or service by trade name, trademark, manufacturer, or otherwise, does not necessarily constitute or imply its endorsement, recommendation, or favoring by

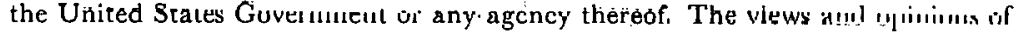
authors expressed herein do not necessarily state or reflect those of the United States Government or any agency thereof.

Printed-in the United States of America

Available from

National Technical Information Service

U.S. Department of Commerce

5285 Port Royal Road

Springfield, VA 22161

Price: Printed Copy $\$ 4.00 ;$ Microfiche $\$ 3.00$ 
Current U.S. energy policy includes many programs directed toward restructuring the energy system in order to decrease U.S. dependence on foreign supplies and to increase our reliance on plentiful and environmentally benign energy forms. However, recent events have led to renewed concern over the direction of current energy policy. This study describes three possible energy strategles and analyzes each in terms of its economic, environmental, and national security benefits and costs. Each strategy is represented by a specific policy. In the first strategy no additional programs or policies are inftiated beyond those currently in effect or announced. The second is directed toward reducing the growth in energy demand, 1.e., energy conservation. The third promotes increased domestic supply through accelerated development of synthetic and unconventional fuels. The analysis focuses on the evaluation and comparison of these strategy alternatives with respect to their energy, economic, and environmental consequences. The results indicate that conservation can substantially reduce import dependence and slow the growth of energy demand, with only a small macroeconomic cost and with substantial environmental benefits; the synfuels policy reduces imports by a smaller amount, does not reduce the growth in energy demand, involves substantial environmental costs and slows the rate of economic growth. These relationships could be different if the energy savings per unit cost for conservation are less than anticlpated, or if the costs of synthetic fuels can be significantly lowered. Given these uncertainties, both conservation and RD\&D support for synfuels should be included in future energy policy. However, between these policy alternatives,' conservation appears to be the preferred strategy.

The results of this study are presented in three reports. The Overview presents a brief discussion of the motiviation for the study, the assumptions and methodologies employed, the results, and the policy implications. The Detalled Projections provides a more complete discussion of the input assumptions, methodology and results of the three strategles analyzed. The Comparative Analysis discusses the projections relative to each other, presents some sensitivity analyses that were performed, and provides a thorough discussion of the policy implications of the regults.

\section{ACKNOWLEDGMENTS}

The authors wish to acknowledge their indebtedness to Hwei-Lin Hong, Dorothy Hatten, Eileen Kleiman, and Scott Rogers for their computational and other assistance in the preparation of this report. This report would not have been possible without the patience and typing skill of Margaret Gallitelli, Susan Walsh, Vanessa Crump and June Martino. 


\section{THIS PAGE}

\section{WAS INTENTIONALLY \\ LEFT BLANK}




\section{CONTENTS}

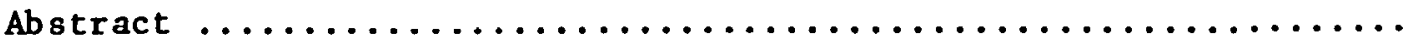

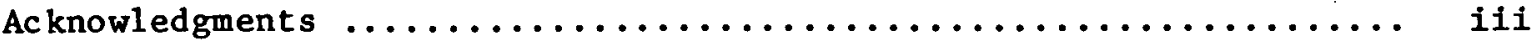

Executive Sumary $\ldots \ldots \ldots \ldots \ldots \ldots \ldots \ldots \ldots \ldots \ldots \ldots \ldots \ldots \ldots \ldots \ldots \ldots \ldots \ldots$

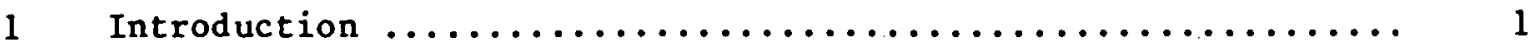

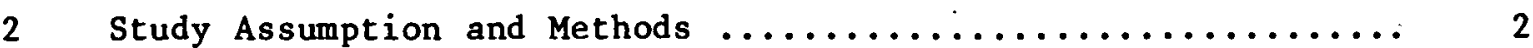

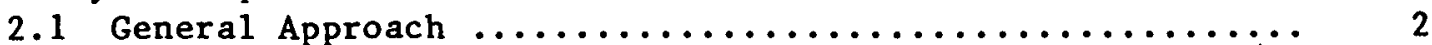

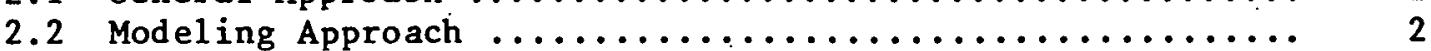

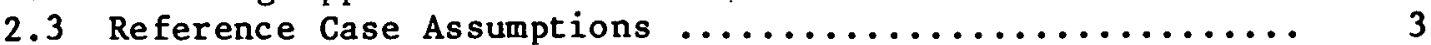

2.3.1 Economic Assumptions ..................... 3

2.3.2 Energy Assumptions .................... 3

2.3.3 Envi ronmental Assumptions ................. 5

2.4 Economic and Energy Assumptions--Policy Cases ......... 5

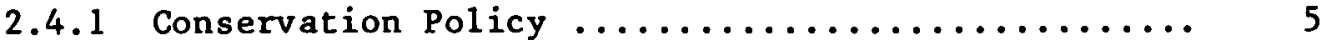

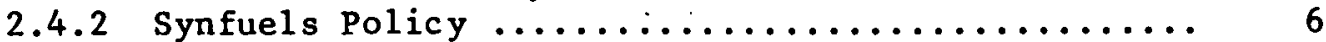

3 Results of the Reference and Policy Scenarios ........... 6

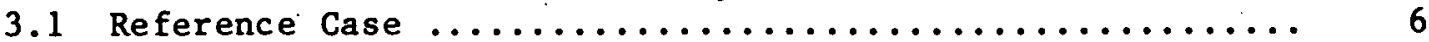

3.1.1 Economic Structure and Growth ............... 6

3.1.2 Development of the Energy System ............. 8

3.2 Comparison of Reference, Conservation, and

Synfuels Policies ........................... 10

4 Policy Implications $\ldots \ldots \ldots \ldots \ldots \ldots \ldots \ldots \ldots \ldots \ldots \ldots \ldots \ldots \ldots \ldots$

References................................. 16

TABLES

1 Conservation Policy, Annual Costs and Energy Savings ....... 5

2 Synthetic Fuel Cost Assumptions ................... 6

3 Reference Projection ............................... 8

4 Comparison of Cases, Economic Summary in $10^{9} \$(1972) \ldots \ldots \ldots 11$

5 Comparison of Cases, Annual Energy Quantities in

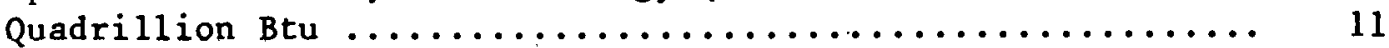

6 Comparison of Cases, Environmental Measures ............. 11

FIGURES

1 Integrated model structure $\ldots \ldots \ldots \ldots \ldots \ldots \ldots \ldots \ldots \ldots \ldots \ldots \ldots \ldots$

2 . Reference case energy quantities ................... 9

3 Comparison of cases, energy use summary $\ldots \ldots \ldots \ldots \ldots \ldots \ldots \ldots 12$ 


\section{EXECUTIVE SUMMARY}

Recent events in Iran and actions by OPEC have again demonstrated that heavy U.S. reliance on imported oil involves considerable risks both to national security and to the economy. The problems have been compounded by heightened concern over the safety of nuclear power. These developments have led to renewed concern over current energy policy and have provided an opportunity to define and clarify its direction. In the process of review it is important to compare and evaluate alternative policy strategies. This study is a contribution to the review of energy policy options.

Specifically, this study describes three possible strategies and. analyzes each in terms of its economic, environmental, and netional security benefits and costs. The first introduces no new policies beyond those already in effect; the second involves a shift of emphasis to energy conservation; and the third focuses on the acceleration of domestic supply expansion. Each strategy is represented by a specific policy. The first strategy is to retain the status quo, and to simply continue those programs and policies that are currently enacted or announced, and under direct control of the Executive Branch (e.g., the oil import quota). The second strategy is analyzed in terms of a set of conservation initiatives constructed by the office of the Assistant Secretary of Conservation and Solar Applications (CSA) and proposed for introduction in FY 1981. The third strategy is analyzed in terms of the synthetic fuels development program proposed by President Carter on July 15, 1979.

These policy alternatives are analyzed over the period 1980-2000 in terms of their effects on the economy, the environment, and national security (indicated by reliance on imports). The analytical framework used for these assessments is the TESOM-LITM system of Brookhaven National Laboratory and Dale $W$. Jorgenson Associates. This framework provides an integrated view of the energy, economic, and environmental systems, fully incorporating the static and dynamic interactions between energy and the economy. The method of analysis is first to project developments under the no new policy strategy, and then to make alternative projections corresponding to each of the more active policy stances.

The principal quantitative results of the policy comparison are summarized in the benefit and cost measures in the accompanying table. The level of U.S. oil imports is an indicator of the degree of attainment of energy security objectives; real GNP is an indicator of economic performance; coal and uranium usage is an indicator of environmental and health effects.

Each energy strategy reduces U.S. dependence on foreign petroleum. At present, about $8 \mathrm{milliom}$ barrels a day (mmbd) of oil are imported; the continuation of present policies (specifically, the oil import quota) reduces this to about 4 mmbd by 1990, and the conservation and synfuels policies achieve still greater reductions. For the longer term, to 2000, present policy holds imports to about $4 \mathrm{mmbd}$, but the synfuels program reduces them to under 1 and the conservation policy eliminates them. 
Summary of Energy, Economy, and

Environmental Effects of Energy Policies

\begin{tabular}{llrrr}
\hline Year & \multicolumn{1}{c}{$\begin{array}{c}\text { Benefit/cost } \\
\text { indicator }\end{array}$} & $\begin{array}{c}\text { No new } \\
\text { policy }\end{array}$ & $\begin{array}{c}\text { Conservation } \\
\text { policy }\end{array}$ & $\begin{array}{c}\text { Synfuels } \\
\text { policy }\end{array}$ \\
\hline \multirow{2}{*}{1990} & Oil imports, $10^{6}$ bbl/day & 4.3 & 2.7 & 2.8 \\
& Real GNP, $10^{9} \$(1972)$ & 1901 & 1899 & 1889 \\
& Coal and uranium use, 1015 Btu/yr & 39 & 35 & 43 \\
2000 & Oil imports & 4.0 & 0.0 & 0.7 \\
& Real GNP & 2469 & 2474 & 2413 \\
& Coal and uranium use & 54 & 42 & 61 \\
\hline
\end{tabular}

Thus, in terms of security objectives, each energy strategy makes a positive contribution, with conservation and synfuels clearly being more effective than the status quo. Another energy objective is to limit total U.S. energy consumption. With continuation of present policy, the growth of primary energy consumption is slowed to under 2.0 percent per annum-considerably lower than the overall rate of economic growth. Under the synfuels policy, energy growth is somewhat more rapid because of the conversion losses associated with the production of synthetic fuels. With the conservation policy, growth in primary energy consumption is virtually halted after 1990 .

Economic growth is projected to continue under each of the three strategies. (Amounts below are in 1972 dollars.) In the no new policy case, real GNP growth averages 2.8 percent per annum to 2000. Relative to this projection, the conservation policy imposes a real cost on the economy through the early 1990s: in 1990 the real GNP level is $\$ 2.2$ billion lower. But toward the end of the century conservation permits faster economic growth, so that by 2000 real GNP is $\$ 4.4$ billion higher. The overall net economic cost of the conservation approach relative to that of no new policy depends on the discount rate used, but for reasonable discount rates the net effect of conservation is a small reduction in the cumulative present value of real GNP changes. The synfuels policy results in greater economic costs: real GNP is below the level of the reference case by $\$ 12.4$ billion in 1990 and by $\$ 56.0$ billion in 2000 . The synfuels policy imposes a significant and permanent cost on the economy in terms of forgone income and production.

The direction and magnitude of the changes in values of environmental and health measures across the policies are governed largely by the changes in the levels of coal and uranium utilization. All the environmental effects assessed (air- and waterborne emissions, person-days lost because of occupational hazards, and population exposure to nuclear radiation) change in the same direction as coal and uranium use. The conservation policy results in lower projected levels of each of these environmental and health indicators than either the reference or the synfuels 
policy because it results in less coal and uranium use. The synfuels policy generates air and water emissions and occupational and safety hazards greater than those of the reference case because these depend predominately on coal usage, which is higher in the synfuels case. Uranium usage is unchanged from the reference to the synfuels case, and therefore population exposure to radiation is the same. Thus, even though specific conclusions concerning the environmental and health impacts of these energy policies cannot be ascertained without information concerning the location of the emitters and the population, it is clear that the synfuels policy results in the greatest environmental and health effects and the conservation policy in the least.

These analytical results have important implications for the design and direction of U.S. energy policy. In terms of national objectives, it is clear that conservation is a major and useful policy instrument. Compared with the present policy situation, a conservation-oriented policy could achieve substantial reductions in energy imports and energy use. Furthermore, it would provide these energy benefits with no major sacrifice in economic performance and with substantial environmental gains. Conservation also compares favorably with a synfuels strategy: it is slightly more effective in reducing oil imports and is noticeably more effective in slowing the growth of total energy use. Also, conservation entails no serious macroeconomic cost, whereas the synfuels policy places a major burden on the economy with consequent reduction in growth of real incomes and material living standards. Finally, in environmental terms, conservation involves benefits while synfuels production involves additional costs relative to the present policy stance.

These findings strongly support the role of conservation as an integral part of future U.S. energy policy, either alone or in combination with supply expansion initiatives. The results should not be interpreted as denying the potential benefits from synfuels programs. The introduction of synfuel technologies at the levels and rates assumed in this analysis secures these benefits only at the risk of significant economic and environmental costs. For synfuels technologies, therefore, programs directed toward cost reduction, performance enhancement, and resnlution of environmental problems related to coal extraction and conversion appear preferable to those promoting accelerated commercial deployment. 


\section{INTRODUCTION}

The recent disruption in world oil markets caused by the Iranian revolution, the rapid escalation in oil prices by OPEC, and the incident at Three Mile Island in Pennsylvania have again demonstrated the interdependencies among the nation's energy, economic, and environmental systems. These events have led to renewed concern over U.S. energy policy and have provided the motivation to define and clarify its direction. It is evident that the dependence of the U.S. on energy system developments can be mitigated only by restructuring the energy system in such a way as to decrease dependence on foreign supplies (which are subject to interruptions and price instability) and to increase reilance on plentiful and environmentally benign domestic energy forms. This restructuring of the energy and economic systems can occur through several types of mechanisms:

- development of options through research and development programs that expand the range of technical substitution possibilities for energy consumption;

- substitutions away from liquids toward other fuels where such adjustments are technically and economically feasible;

- reductions in the energy intensities of production and consumption activities by substitutions that lower energy inputs;

- restructuring of spending patterns away from energy-intensive goods and services;

- expansion of the domestic petroleum reserve base and domestic petroleum (and liquid fuel) output;

- development of new energy supply alternatives that more fully utilize the domestic resource base.

Many of these changes will occur as natural responses by consumers and industry to the uncertain avallability and increasing cost of conventional fuels. However, government energy policy can contribute to the speed of this transition and can provide incentives to encourage the more difficult or expensive adjustments.

Current U.S. energy policy includes many programs directed toward these ends. The intention of current policy is to provide a comprehensive program that reduces U.S. dependence on imports and increases use of plentiful domestic resources through both demand reduction and supply expansion. However, many issues have arisen in the design and implementation of energy policy, and controversy continues over the components and direction of future policy. In formulating the direction of policy, it is important to examine the relative merits of each available strategy to ensure that the chosen policy yields the best combination of economic, environmental, and security benefits relative to the costs incurred. The analysis in this report is directed to such an examination.

The range of future energy policy directions can be characterized in terms of three alternative strategies: no new policy, demand reduction, or supply expansion. Specific policy representations of each of these strategies are analyzed to determine their relative impacts. The first 
strategy is to pursue no additional policies or programs beyond those currently announced or in place (reference case). The second is to direct policy toward reducing the growth in energy demand, i.e., energy conservation (conservation case). The third is to promote increased domestic supply primarily through accelerated development of so-called synthetic and unconventional fuels (synfuels case). The analysis that follows is focused on the evaluation and comparison of these strategy alternatives with respect to their energy, economic, and environmental consequences.

\section{STUDY ASSUMPTION AND METHODS}

\subsection{General Approach}

Each of the strategies is analyzed by developing an inlegrated projection of the nation's energy and economic systems. The projection measures the energy, economic, and envi ronmental impacto associated wlll the implementation of a set of energy policies. Each projection is obtained by applying an integrated energy-economy model (described in the followIng section) to the estimation of the structure and growth of the U.S. energy and economic systems.

The reference projection, representing the first strategy, is deve1oped on the premise that only those policies currently enacted or announced and under direct control of the Executive Branch are in effect. The second strategy is developed by introducing into the reference projection a set of new conservation initiatives suggested by the office of the Assistant Secretary of Conservation and Solar Applications. The third strategy is developed from the reference projection by assuming inplementation of the President's synthetic fuels program as proposed in his speech of July 15, 1979.

\subsection{Modeling Approach}

The modeling approach used in this study employs an integrated set of technological and economic models to explore the national energy and economy responses to proposed energy policies. The integrated system is composed of three component models: an aggregate structural model of economic growth, a comprehensive energy system model, and a detailed input-output model for the U.S. economy. This system of models has been integrated to provide a comprehensive long-run representation of the U.S. energy and economic systems and energy-economy interactions. 1,2

The economic growth mudul lo the Dale W. Jurgenson Associates (DJA) Long-term Interindustry Transactions Model (LITM). ${ }^{3}$ LITM provides a flexible, interindustry representation of sectoral production and final demand, and captures the combined influences of productivity, investment, and labor supply on the expansion of U.S. productive capacity over the 
long run. The detailed technological model of energy supply, conversion and end-use demand is the Time-stepped Energy System Optimization Model (TESOM) developed at Brookhaven National Laboratory. ${ }^{4}$ TESOM represents the range of feasible energy resource and technology substitutions for the U.S. energy system. It is formulated as a mathematical programming model to optimize the mix of supply, conversion, and demand technologies to meet a set of energy service demands. TESOM is stepped through time to capture the dynamics of energy prices, technology development, and service demand. The input-output model is that developed jointly by Brookhaven National Laboratory and the University of Illinois. 5 This detailed input-output model is used to transform the sectoral output and consumption levels modeled in LITM into a restructured set of demands for energy services in physical units.

Figure 1 is a representation of the integrated modeling structure indicating the flow of information among the component models. Solutions to the system of models for any given set of analytical assumptions are found through a process of iteration and adjustment until consistency among model components is obtained. The iterative process is carried out for each of the years in the study, with the solution moving sequentially forward over the years involved.

\subsection{Reference Case Assumptions}

2.3.1 Economic Assumptions. The LITM economic model requires input assumptions on future population, government expenditure and revenue policies, and unemployment rate. The Census Bureau's Series II population projections (fertility rate of 2.1) were used to derive figures on the future population. Labor force participation rates are endogenous to the model and are not specified as assumptions. The unemployment rate is assumed to follow a cyclical rate, from 6.0 percent in 1978 to 5.6 percent in 1985, and then to decline slightly over the rest of the forecast period. A slight increase in government purchases relative to the rest of the economy (from 19.4 percent of real GNP in 1980 to 19.9 percent by 2000 ) is assumed, reflecting current trends of government programs including new developments in the health, services, energy, and defense areas. Government transfers and tax revenues are assumed to rise approximately in line with the economy as a whole. Most of the productivity effects in the model are endogenous and are not specified as assumptions; the energy supply and productivity information is obtained from the TESOM model.

2.3.2 Energy Assumptions. The reference case projection incorporates a variety of energy system assumptions: prices and availabilities of energy resources; capital and operating costs for electricity generation, synthetic fuel production, and end-use devices; limits on the market penetration rates. for new energy technologies; and changes in efficiencies of fuel conversion over the 1980 to 2000 time horizon. The energy assumptions include the impacts of policy initiatives or actions 


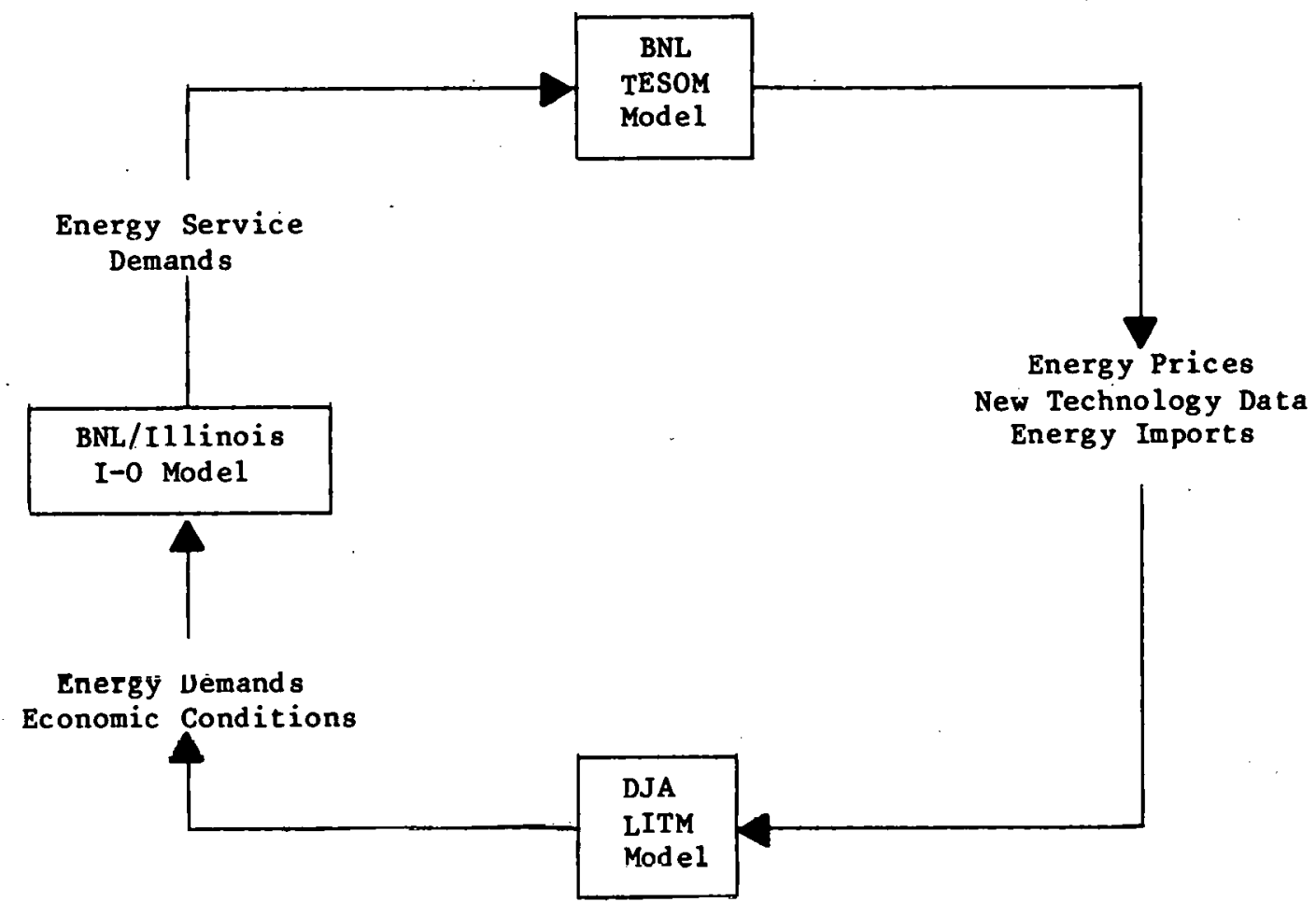

Figure 1. Integrated model structure

already legislated or announced and under control of the Executive Branch. In particular, the reference case incorporates the oil import quotas announced by President Carter in his energy initiatives speech of July 15, 1979. These quotas require that future annual levels of oil imports never exceed the 1977 level, and that they be reduced to one-half that level by 1990 .

Domestic pricing assumptions are based on the phased decontrol of domestic oil prices by 1981. A windfall profits tax (proposed but not enacted) is not included. The U.S. Department of Energy NEP II High Price Trajectory is assumed for world dil prices, 6 in which the world oil price rises at an average annual rate of 3.3 percent from $\$ 20$ per barrel in 1980 to $\$ 38$ by 2000 (in constant 1978 dollars). (These correspond to prices of 2.28 and 4.33 in 1972 dollars per million Btu). Domestic natural gas prices are assumed to be deregulated by 1985 and then to rise rapidly until they approach the crude oil price, from $\$ 0.78$ per million Btu in 1980 to $\$ 4.33$ by 2000 ( 1972 dollars).

Domestic oil and gas production possibilities are determined by applying a Hubbert curve analysis to the U.S. Geological Survey mean geology estimates. ${ }^{7}$ Nuclear electric generating capacity is assumed to reach 155 gigawatts during the 1985 to 1990 period and to increase to 215 gigawatts by 2000 . 
2.3.3 Environmental Assumptions. A set of measures of environmental effects is generated from each TESOM solution by using emission and conversion factors associated with specific technologies. The impacts measured include air- and waterborne emissions, land use, occupational injuries, and also items such as radiation exposure levels. The emission and conversion factors are based on the assumption that best currently available control technologies are used in each process in the system but their effectivness does not change over time.

\subsection{Economic and Energy Assumptions--Policy Cases}

2.4.1 Conservation Policy. The conservation policy analyzed is the proposed FY 1981 program of CSA. Costs, both government and private, and energy savings are based on the Consolidated Ranking of FY 1980 Decision Packages and supporting materials that were prepared by CSA personnel and incorporate the following programs:

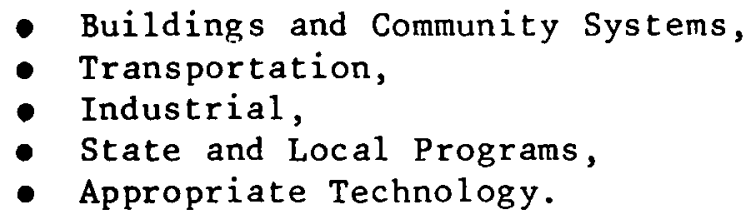

From this conservation program information, the total discounted public and private expenditures for each subprogram are annualized to obtain total expenditures in each year over the period 19812000. The annual expenditures are then separated into investment purchases and labor requirements as appropriate for each subprogram. Since investment adds to a permanent although depreciating capital stock, the capital input requirements are expressed in terms of the services generated from this capital stock. The capital services and labor services series represent the annual costs associated with the energy savings from the conservation policy. Total costs and energy savings are summarized in Table 1. The values of the electricity (primary energy equivalent), petroleum, and gas savings, i.e., the direct energy benefits of the CSA programs, are determined in the combined model system.

\begin{tabular}{|c|c|c|c|c|}
\hline \multirow[t]{3}{*}{ Annual } & \multicolumn{3}{|c|}{$\begin{array}{l}\text { Table 1 } \\
\text { Conservation Policy, } \\
\text { Costs and Energy Savings }\end{array}$} & \\
\hline & \multicolumn{2}{|l|}{1990} & \multicolumn{2}{|l|}{2000} \\
\hline & $\begin{array}{c}\text { Program costs } \\
\left(10^{9} 1972 \$\right)\end{array}$ & $\begin{array}{l}\text { Energy } \\
\text { savings } \\
\text { (quads) }\end{array}$ & $\begin{array}{l}\text { Program costs } \\
\left(10^{9} 1972 \$\right)\end{array}$ & $\begin{array}{l}\text { Energy } \\
\text { savings } \\
\text { (quads) }\end{array}$ \\
\hline Building/commity systems & 7.6 & 5.6 & 6.1 & 10.0 \\
\hline Transportation & 4.0 & 1.9 & 16.5 & 7.4 \\
\hline Industrial & 2.0 & 2.5 & 1.1 & 4.2 \\
\hline State and local & ** & $* *$ & $\star \star * *$ & $* *$ \\
\hline Appropriate technology & 0.6 & 0.2 & 0.4 & 0.6 \\
\hline Total* & 14.2 & 10.3 & 24.2 & 22.3 \\
\hline
\end{tabular}

* Totals may not add because of roinding. $\star *<0.05$. 
2.4.2 Synfuels Policy. The synfuels program is modeled in terms of President Carter's synthetic fuel proposal of July 15, 1979, which called for an incremental production goal of 2.5 million barrels per/day (crude oil equivalent) of synthetic fuels by 1990. The assumed allocation of this increment is as follows:

\begin{tabular}{lr} 
& Million b \\
\cline { 2 - 2 } Coal liquids* & 1.25 \\
Hi-Btu coal gas & 0.25 \\
Shale oil & 0.40 \\
Biomass gas & 0.10 \\
Unconventional gas $\quad$ Total & 0.50 \\
\multicolumn{1}{c}{ Total } & 2.50
\end{tabular}

Synthetic fuels production is assumed to continue to increase during the pnst-1990 period at an aniual rate of 10 percent, somewhat more moderately than in the reference projection (but from a significantly higher 1990 base). The synfuels cost assumptions are given in Table 2 .

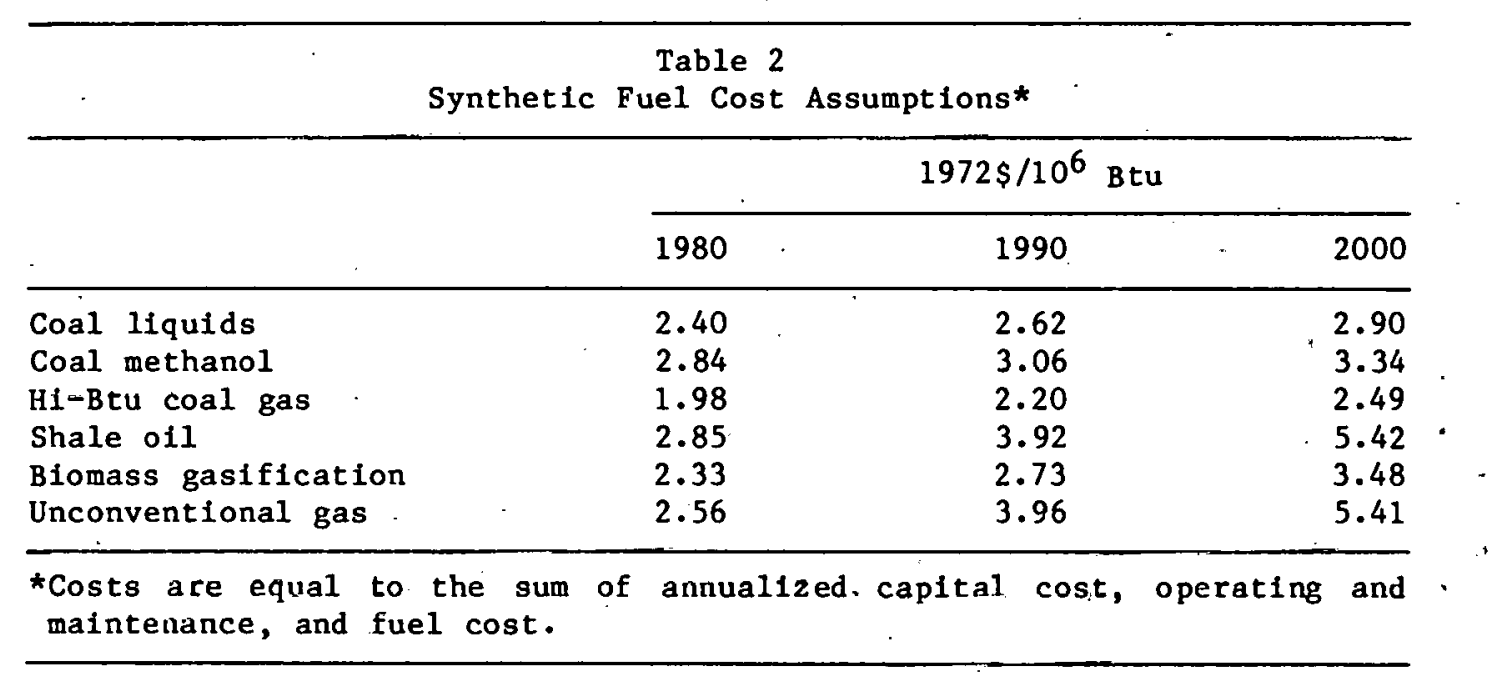

3. RESULTS OF THE REFERENCE AND POLICY SCENARIOS

A detailed discussion of the reference and policy scenarios is presented in another volume of this study. 8

\subsection{Reference Case}

3.1.1 Economic Structure and Growth. The principal features of the reference projection regarding the growth and structure of the U.S. economy are as follows:

‡

Coal liquids production includes methanol and coal liquefaction output. 
- Economic growth continues at a positive but declining rate.

- Growth in productivity becomes relatively more important as labor force expansion slows.

- The pattern of final expenditures changes gradually, with consumption becoming relatively more important.

- The pattern of production undergoes structural change: as the relative importance of agriculture, extractive, and energy activities diminishes, that of manufacturing stabilizes, and that of transportation, communications, trade, and services increases.

- As a result of both long-run structural change in production and energy changes, the importance of labor and energy is reduced relative to that of capital.

The principal labor, output, and productivity measures for this projection are presented in Table 3. Projected GNP growth averaging 2.8 percent per annum through 2000 is sufficient to sustain a continuing increase in material living standards: real GNP per capita increases at an average annual rate of 1.8 percent over the forecast horizon. The progressive slowing of economic growth rates within the projection reflects the slowing both of labor force growth (due to changes in age structure of the population) and of productivity advance (due, partly to continuing escalation of real energy prices). Through the early $1990 \mathrm{~s}$, productivity and employment increases contribute about equally to real GNP growth; subsequently, productivity increases account for the greater share. Productivity changes include effects due to increases in the efficiencies of labor and capital, to the capital-labor ratio, and to changes in the sectoral mix of production. (Projected rates of productivity growth are substantially lower than the 2 to 2.5 percent rates experienced before the recent rise in energy prices.)

The reference projection suggests only moderate changes in the pattern of agggregate purchases, with consumption showing a slight increase and investment a slight decrease in relative importance. Consumption remains the principal use of final output, and real per capita consumption is projected to increase by over 50 percent between 1980 and 2000. Until 1990, present trends in the pattern of consumption spending are prujected to continue, with manufacturing goods showing a small reduction and services accounting for an increasing share of final spending. After 1990, the shares of manufacturing and services stabilize. The changing pattern of final demand for energy is significant. To 1990 , the combined influences of real energy price increases, relatively strong economic growth, and the inability to adjust energy-consuming capital stock instantaneously result in an increase in the energy share of final demand. After 1990, when constraints on capital stock turnover become less restrictive (i.e., when demand adjustments are more complete), energy's share of final expenditure declines monotonically.

The operation of the economy in terms of how output is produced is also projected to change. The aggregate composition of inputs to production is given by the capital, labor, energy, and materials coefficients. Production becomes steadily more capital intensive and less 
Table 3

Reference Projection

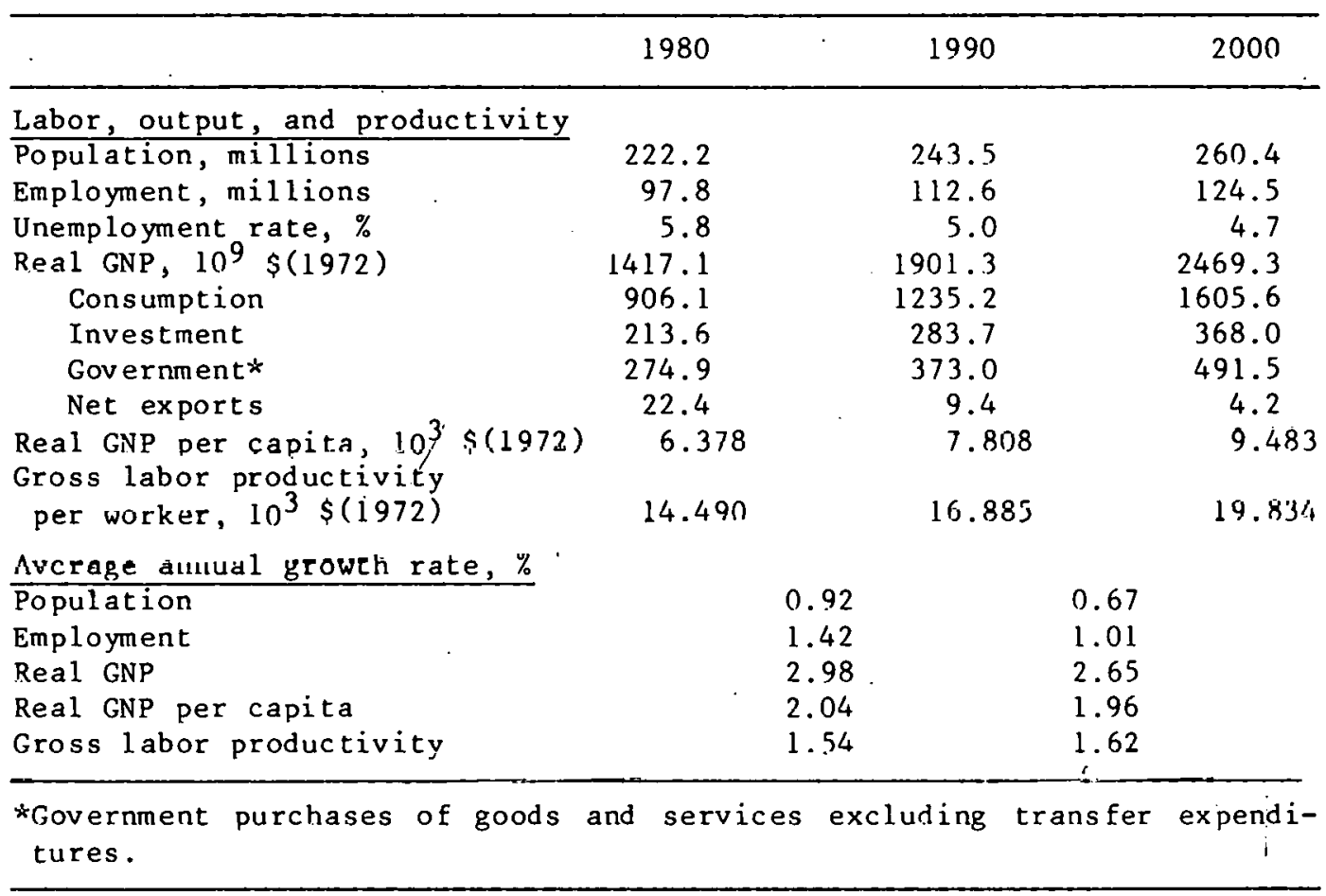

labor intensive. Equally important is the declining intensity of energy use in aggregate production as evidenced by reductions in energy's share of total inputs and in the energy-capital ratio. This decline reflects the impacts of past and continuing increases in energy prices which induce producers to redirect expenditures, substituting other factors for energy.

3.1.2 Development of the Energy System. The projected development of the energy system is summarized in Figure 2. Total energy service demand grows at a decreasing rate, slowing from an average annual rate of 2.8 percent during 1980-1990 to 2.2 percent during $1990-2000$, as economic activity becomes less energy intensive. The structure of demands changes with the evolving structure of the economy. The share of total energy services required by the industrial sector shows a slight increase over the 1980-2000 period, largely due to the increasing importance of the petrochemicals industry, tempered somewhat by slower growth in process heal requirements. The growing importance of the commercial sector of the economy results in increasing demands for energy services by that sector. In contrast, the slower future growth of population in conjunction with shifts toward less energy intensive behavior patterns results in a slowing of the growth in residential energy service demands. This slower growth outweighs the increased growth in commercial activity and results in a slight decline in the combined residential and commercial 


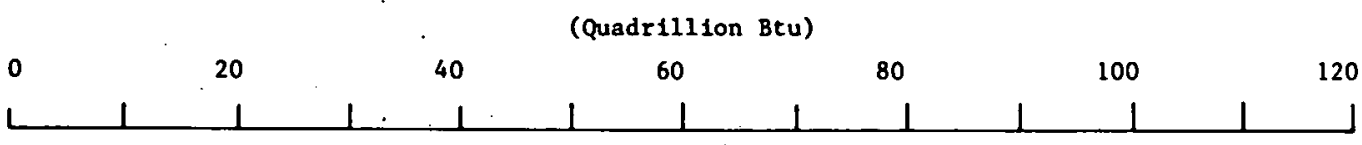

1980

ENERGY SERVICES

DELIVERED ENERGY*

PRIMARY ENERGY

\begin{tabular}{|c|c|c|c|c|c|c|c|c|}
\hline $\begin{array}{l}R / C \\
11\end{array}$ & $\begin{array}{l}I \\
18\end{array}$ & & $\begin{array}{l}T \\
4\end{array}$ & \multicolumn{3}{|c|}{ (33) } & \multirow{2}{*}{\multicolumn{2}{|c|}{ (59) }} \\
\hline SOL. & \multicolumn{3}{|c|}{$\begin{array}{l}\text { LIQUID } \\
\quad 31\end{array}$} & & $\begin{array}{l}\text { GAS } \\
14\end{array}$ & $\begin{array}{l}\text { ELEC + }+ \\
\text { HEAT } 8\end{array}$ & & \\
\hline \multicolumn{2}{|c|}{$\begin{array}{l}\text { DOM OIL + } \\
\text { SHALE }\end{array}$} & \multicolumn{3}{|c|}{$\begin{array}{l}\text { DOM + IMP } \\
\text { GAS } 18\end{array}$} & \multicolumn{2}{|c|}{${ }_{18}^{\text {COAL URANIUM }}$} & $\begin{array}{c}\text { OIL IMPORTS } \\
16\end{array}$ & $\begin{array}{c}\text { REN } \\
6\end{array}$ \\
\hline
\end{tabular}

1990

ENERGY SERVICES

DELIVERED ENERGY*

PRIMARY ENERGY

\begin{tabular}{|c|c|c|c|c|c|c|c|c|c|}
\hline $\begin{array}{l}R / C \\
14\end{array}$ & & $\begin{array}{l}I \\
24\end{array}$ & & $\begin{array}{l}\mathbf{T} \\
5\end{array}$ & \multicolumn{2}{|c|}{ (43) } & \multirow[b]{2}{*}{$(68)$} & & \\
\hline $\begin{array}{l}\text { SOLID } \\
11 .\end{array}$ & \multicolumn{2}{|r|}{$\begin{array}{l}\text { LIQUID } \\
26\end{array}$} & & & $\begin{array}{l}\text { GAS } \\
18\end{array}$ & $\begin{array}{ll}\text { ELEC }+ \\
\text { HEAT } 12\end{array}$ & & & \\
\hline $\begin{array}{l}\text { DOM OIL }+ \\
\text { SHALE }\end{array}$ & 20 & $\begin{array}{l}\text { DOM + IMP } \\
\text { GAS }\end{array}$ & 20 & & & & $\begin{array}{c}\text { URA- } \\
\text { NIUM } \\
9\end{array}$ & $\begin{array}{c}\text { OIL } \\
\text { IMPORT } \\
9\end{array}$ & $\begin{array}{l}\text { RENEW- } \\
\text { ABLES } \\
9\end{array}$ \\
\hline
\end{tabular}

2000

ENERGY SERVICES

DELIVERED ENERGY*

PRIMARY ENERGY

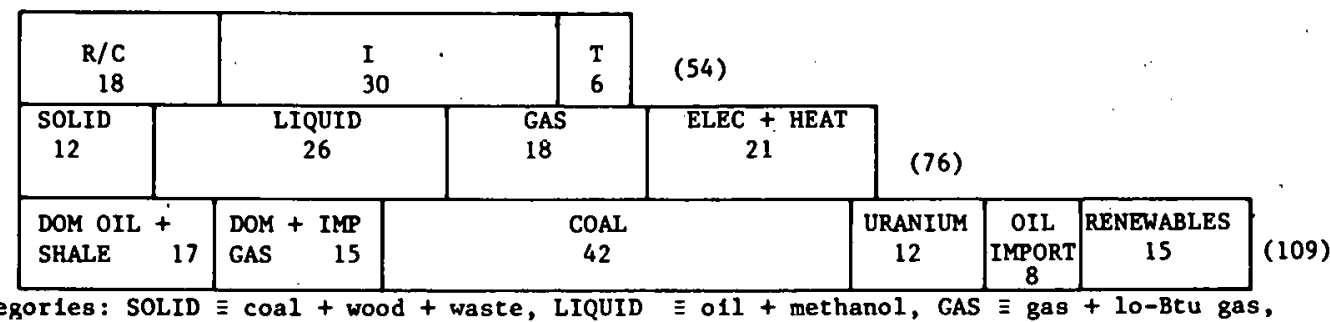

* Delivered Energy Categor1es: SOLID $\equiv$ coal + wood + waste, LIQUID $\equiv 011+$ methanol, GAS $\equiv$ gas + 10-Btu gas, ELEC + HEAT $\equiv$ electric + direct heat.

\section{Figure 2. Reference Case Energy Quantities}


share of energy service demands. The share for transportation declines somewhat because of the smaller role of this sector over time and shifts in behavior patterns away from private ground transportation toward the more energy efficient air, bus, and electric rail modes.

The mix of delivered fuels which fulfills these energy service demands changes significantly over the projection period. The constraints on the use of liquid fuels due to import quotas, lack of growth in domestic oil reserves, lags in the development of synthetic liquids and shale oil, and the high prices of the liquids that are available result in a rapid shift away from liquid fuels between 1980 and 1990 . The substitution comprises increased use of coal for process heating, gas for space heating and air conditioning, and electricity for residential, commercial and industrial purposes. After 1990, increased availability of synthetic 1 iquids results in dampening of the previous substitution trends, particularly the trend toward electriflcation.

The rate of growth of primary energy utilization slows significantly, from an annual rate of 1.7 percent during 1980-1990 to 1.2 percent during 1990-2000. Total primary energy input per year rises from 82 quads in 1980 to 109 in 2000 . The pattern of energy resource use follows the end-use changes outlined above, particularly the declining share of oil and gas: the total use of petroleum is projected to drop from 37 quads in 1980 to 25 in 2000 .

The average efficiency of producing delivered energy from energy resources declines over time as the system shifts toward greater reliance on electricity and synthetic fuels. However, efficiency improvements in end-use devices, the turnover in vintage capital stocks, and shifts towards electricity and solar utilizing devices (with high end-use device efficiencies) lead to increases in the efficiency with which energy service demands are met by delivered energy forms. The improvements in demand efficiencies far outweigh the losses in conversion efficiency and result in gains in the overall system efficiency. Thus, the ratio of total energy service demands to total primary energy increases, from 0.40 in 1980 to 0.45 in 1990 and 0.49 in 2000 .

\subsection{Comparison of Reference, Conservation, and Synfuels Policies}

Tables 4, 5, and 6 and Figure 3 summarize the relationships among the reference, conservation, and synfuels cases. A more detailed comparison is presented in another volume, 9

The conservation policy succeeds in reducing the overall energy requirements of the U.S. and -- what is most important -- its reliance on imported petroleum. Compared with the reference case, aggregate primary energy consumption is 10 quads less in 1990 and 22 less in 2000 . The conservation program reduces imported petroleum requirements by 41 percent in 1990 and eliminates them by 2000 . The remaining reductions in primary energy are due largely to reduced coal and nuclear use. Synthetic fuel pr duction and electricity generation are both lower than in the reference case.

The conservation policy results in a small economic change relative to the reference projection: a real GNP smaller by $\$ 2.2$ billion (1972 dollars) in 1990 but greater by $\$ 4.4$ billion (1972 dollars) in 2000 . In 1990 the conservation program costs more than the energy displaced (oil 


\begin{tabular}{|c|c|c|c|c|}
\hline \multicolumn{5}{|c|}{$\begin{array}{c}\text { Table } 4 \\
\text { Comparison of Cases, } \\
\text { Economic Summary in } 10^{9} \$(1972)\end{array}$} \\
\hline & & & Difference & \% Change \\
\hline & Reference case & Conservation & & \\
\hline $\begin{array}{l}1990 \text { GNP } \\
2000 \text { GNP }\end{array}$ & $\begin{array}{l}1901.3 \\
2469.3\end{array}$ & $\begin{array}{l}1899.1 \\
2473.7\end{array}$ & $\begin{array}{r}-2.2 \\
4.4\end{array}$ & $\begin{array}{r}-0.12 \\
0.18\end{array}$ \\
\hline & Reference case & Synfuels. & & \\
\hline $\begin{array}{l}1990 \text { GNP } \\
2000 \text { GNP }\end{array}$ & $\begin{array}{l}1901.3 \\
2469.3\end{array}$ & $\begin{array}{l}1888.9 \\
2413.3\end{array}$ & $\begin{array}{l}-12.4 \\
-56.0\end{array}$ & $\begin{array}{l}-0.65 \\
-2.27\end{array}$ \\
\hline & Synfuels & Conservation & . & \\
\hline $\begin{array}{l}1990 \mathrm{GNP} \\
2000 \mathrm{GNP}\end{array}$ & $\begin{array}{l}1888.9 \\
2413.3\end{array}$ & $\begin{array}{l}1899.1 \\
2473.7\end{array}$ & $\begin{array}{l}10.2 \\
60.4\end{array}$ & $\begin{array}{l}0.54 \\
2.50\end{array}$ \\
\hline
\end{tabular}

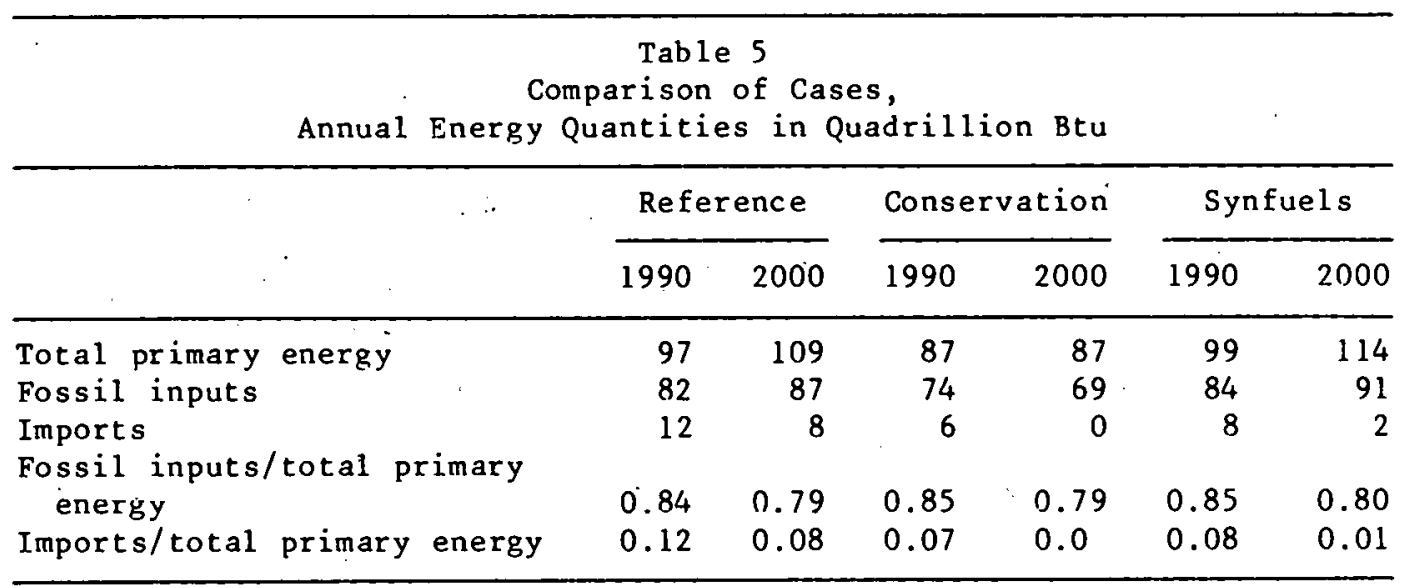

Table. 6

Comparison of Cases,

Environmental Measures

\begin{tabular}{|c|c|c|c|c|c|c|}
\hline & \multicolumn{2}{|c|}{ Reference } & \multicolumn{2}{|c|}{ Conservation } & \multicolumn{2}{|c|}{ Synfuels } \\
\hline & 1990 & 2000 & 1990 & 2000 & 1990 & 2000 \\
\hline $\begin{array}{l}\text { Airborne emissions, } 10^{6} \text { tons } \\
\text { Waterborne emissions } 10^{6} \text { tons } \\
\text { Person-days lost, } 10^{3} \\
\text { Population exposure, } \\
10^{6} \text { man-rems/yr. }\end{array}$ & $\begin{array}{r}34.5 \\
1.9 \\
667.0\end{array}$ & $\begin{array}{r}39.5 \\
2.3 \\
903.8\end{array}$ & $\begin{array}{r}33.3 \\
1.6 \\
607.0\end{array}$ & $\begin{array}{r}32.7 \\
1.8 \\
668.6\end{array}$ & $\begin{array}{r}38.1 \\
2.0 \\
725.5\end{array}$ & $\begin{array}{r}46.4 \\
2.7 \\
1122.7\end{array}$ \\
\hline
\end{tabular}



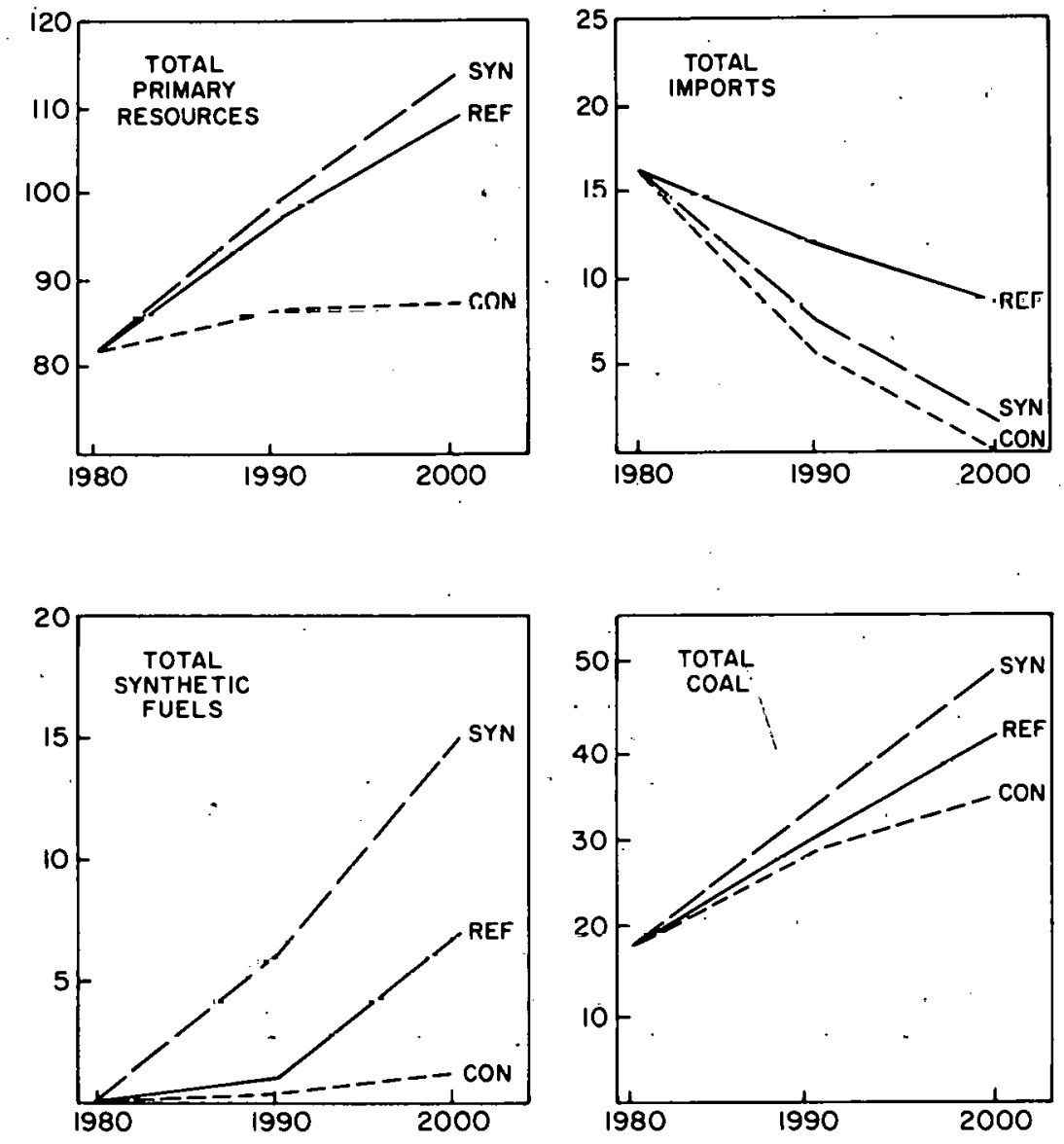

Figure 3. Comparison of cases, energy use summary (quadrillion Btu) 
and gas); by 2000 it provides an energy alternative that costs less than the ofl, gas, synthetic fuels, and electricity it displaces.

The environmental outlook under conservation is also better than in the reference projection. Less coal use for electricity generation and synthetic fuels production results in less air- and waterborne emissions and fewer occupational injurles. The lower electricity usage also requires fewer nuclear plants and thus causes less population exposure to nuclear radiatión.

The synfuels policy, compared with the reference case, succeeds in reducing U.S. dependence on Imports (although to a lesser extent than the conservation policy). Synthetic fuels displace 35 percent ( 4.2 quads) of U.S. annual import requirements in 1990 and 80 percent (6.7 quads) in 2000. The policy does not reduce aggregate energy consumption; in fact, because of the above-average conversion losses in synfuels production, aggregate annual energy consumption is higher than in the reference case by 2.0 quads in 1990 and 4.2 quads in 2000. However, this increased consumption is supplied entirely from domestic resources (coal).

The synfuels policy imposes a net economic cost on the economy: real GNP is lower than in the reference case, by 0.7 percent ( 12.4 billion 1972 dollars) in 1990 and 2.3 percent ( 56.0 billion 1972 dollars) in 2000 . Thus, in all years, real output and incomes are reduced by the synfuels measures, and the rate of economic growth is slowed.

The increased coal production required by the synfuels program results in increases in most of the environmental measures -- those associated with coal mining (injuries, deaths, and waterborne emissions) and coal conversion (air- and waterborne emissions). -- as synfuels replace "cleaner" conventional 1iquids and gases of the reference projection.

Both the conservation and the synfuels policies are more effective than the continuation of current policy in reducing U.S. reliance on forelgn petroleum and gas. The conservation approach results in a lower aggregate energy intensity of the U.S. economy. The conservation policy provides a smaller economic cost to the U.S. as compared to the synfuels program. Only the conservation policy provides energy (or energy displacement). that is cheaper than the energy that would otherwise be used. In contrast, the synfuels program provides energy that is more expensive than the energy it displaces. For example, in 1990 the cost of energy with conservation is $\$ 1.38$ (1972 dollars) per million Btu while the cost of energy with the synfuels policy is $\$ 3.45$ (1972 dollars) per million Btu. The synfuels approach implies an economy that is more intensive in capital, labor, and energy input, and less intensive in use of intermediate materials, than the economy under the conservation policy. But, the synfuels policy also results in lower productivity of capital and labor, so that real incomes and output are lower. than with the conservation policy. Levels of environmental measures are lower with the conservation policy than with the synfuels pollcy or with the reference projection.

\section{POLICY IMPLICATIONS}

The results of this analysis yield important implications for the focus and direction of U.S. energy policy. All of the strategies consid- 
ered succeed in reducing dependence on imports and slowing the growth in energy demand. In the reference projection, import quotas and domestic oil and gas price decontrol reduce oil imports to half their current levels, and also lower the annual growth of primary energy consumption and shift energy use patterns toward greater utilization of coal. The conservation or the synfuels policy further reduces U.S. import requirements; the former is slightly more effective, but either one permits almost total elimination of imports by 2000. The conservation policy has the additional benefit of virtually halting the growth in aggregate primary energy demand by 1990 , but even the large-scale introduction of synthetic fuels results in only marginally higher primary energy consumption than in the reference case. Thus, to different degrees, a slowing of the growth in energy use is evident under all three strategies.

In the environmental and economic areas, the strategies differ significantly. Substantial environmental benefits result from energy conservation, but these are. increasingly lessened in shifting to the policies of the reference and the synfuels projections. For the economy, the synfuels policy imposes a significant net economic cost, with a growth in real GNP lower than for either the reference or the conservation projection. The economic results of the conservation policy are mixed: it leads to lower real output than the reference projection in 1990 but higher output in 2000 ; at reasonable discount rates, it results in a small net economic cost.

These comparisons make it clear that conservation alone, regardless of other policies, can substantially reduce import dependence and slow the growth of energy demand, and $c$ an achieve these results with only a small macroeconomic cost and with substantial environmental benefits. The conservation policy compares favorably with the synfuels policy: the latter is slightly less successful in reducing imports and provides no mechanism for reducing demand growth; it has substantial environmental costs rather than benefits; and its impact on economic performance is much more severe.

These conclusions do not deny a potential benefit from proposed synfuels programs, and they should not be interpreted as advocating de-emphasis of supply expansion. The more favorable economic results of the conservation policy as compared to the synfuels policy are directly attributable to the costs of each. A synfuels program aimed at reducing the cost of synthetic fuel production has the potential for mitigating the negative economic aspects of focusing on the accelerated commercial deployment of current technologies.

The impacts on economic performance determined for each policy case are sensitive to, inter alia, the actual policy representations introduced into the reference projection. The economic effects of the conservation policy depend on the timing of conservation expenditures, the pattern of energy savings by fuel typc, and the effectivuluss of the policy. An anal= ysis performed on the time pattern, and hence the magnitude of annual conservation expenditures within the same total discounted expenditure, did not change the nature of the results; even the case least advantageous to conservation leads to significantly lower costs to the economy than does the synfuele policy.

Sensitivity analyses were also conducted for the conservation policy in terms of the division of energy savings among petroleum, natural gas, and electricity. Variations in this division can affect the timing and 
magnitude of net economic benefits or costs. As electricity is the most expensive in terms of its input claims on the economy, the greater the share of electricity in the energy saved, the greater the net economic benefits from conservation policy. Thus, in designing conservation policies that promote jointly national energy, economic, and environmental objectives, the net economic benefits are greatest (or the costs are least) from strategies that emphasize substitutions away from petroleum and electricity.

Regarding the effectiveness of conservation policy, the controllable instrument is the programmed expenditure of public funds. The public expenditures and programs, in turn, motivate the private sector to redirect expenditure patterns toward conservation activities. These ultimately provide the energy savings from conservation. However, the levels of private expenditure and the resultant energy savings are outputs of the policy and, to some extent, are uncontrollable. For the given expenditures, the energy savings could be significantly less than anticipated; or, for the anticipated energy savings, the cost could be substantially higher. Analysis suggests, however, that only in the extreme cases would the macroeconomic cost be similar in magnitude to that incurred with the synfuels program.

The issue of policy effectiveness extends also to the synfuels policy. In developing this projection, the capital and labor costs for each synfuel technology were assumed to be invariant over time, without regard to cost reductions due to learning effects, technical improvement, economies of scale, or other means of productivity enhancement. Cost reductions for the synthetic and unconventional fuels technologies can dramatically reduce the net economic cost associated with this policy. Lowering the costs of such fuels to the point where they are competitive with the energy provided from conservation reduces the adverse macroeconomic impact from the synfuels policy by more than half.

Thus, it is possible to envision circumstances under which the advantage of the conservation policy over the synfuels policy is reduced. In terms of macroeconomic effects however, for synfuels to be economically superior to conservation requires a combination of extreme changes in costs and in other conditions that has a very adverse effect on conservation and a highly favorable one on synfuels. Even allowing for this possibility, two clear policy conclusions emerge from this analysis:

- Conservation has a definite role in reducing energy imports and energy growth in a way that is economically and environmentally attractive.

- The premature, large-scale introduction of costly, existing synthetic fuel conversion technologies results in reduced energy imports, but at the cost of lower economic growth and undesirable environmental effects. A research, development, and demonstration program aimed at reducing the costs of synfuel supply and lowering the environmental impacts of coal and shale extraction and conversion could reduce or eliminate the negative economic and environmental aspects of the synfuels policy analyzed here.

The principal implication of these analytical results is that active programs for energy conservation and continued RD\&D support for synthetic and unconventional fuels both should be integral components of future U.S. energy policy. 
1. Groncki, P.J. and Marcuse, W., The Brookhaven Integràted Energy/ Economy Modeling System and Its Uses in Conservation and Policy Analysis, BNL 51056, 1979.

2. Lukachinski, J., Groncki, P.J., Tessmer, R.G., Goettle, R.J., and Hudson, E.A., An Integrated Methodology for Assessing Energy-Economy Interactions, BNL 26452, 1979.

3. Hudson, E.A. and Jorgenson, D.W., The Long-Term Interindustry Transactions Model: A Simulation Model for Energy and Economic Analysis, Final Report to the Applied Economics Division, Federal Preparedness Agency, General Services Administration, 1977.

4. Kydes, A.S., The Brookhaven Energy System Optimisation Model: Its Variants and Uses, BNL 50873, 1978.

5. Fraser, J.T., Documentation of the Brookhaven Energy $\mathrm{I}-0$ and I-O/BESOM Linkage, BNL 50856, 1978 .

6. National Energy Plan II, U.S. Department of Energy, Washington, DC, May 1979.

7. Annual Report to Congress 1978, Vol. 3, DOE/EIA-0173/3, U.S. - Department of Energy, U.S. Department of Energy, Washington, DC.

8. Davitian, H., Groncki, P.J., Kleeman, P., Lukachinski, J., Goettle IV, R.J., and Hudson, E.A., A Strategic Cost-Benefit Analysis of Energy Policies: Detailed Projections, BNL $51127, \cdot 1979$.

9. Davitian, H.; Groncki, P.J.; Kleeman, P., Lukachinski, J., Goettle IV, R.J. and Hudson, E.A. A Strategic Cost-Benefit Analysis of Energy Policies: Comparative Analysis, BNL 51128, 1979. 